\title{
A New Perspective on the Creation of Neologisms
}

\author{
LIN Ming-chang \\ Fo Guang University, \\ Department of Chinese Literature and Applications \\ lin747@gmail.com
}

\begin{abstract}
This article proposes a new research perspective towards the reasons for devising neologisms. Instead of reflecting upon this topic from the perspective of "a word", the language user's psychological requirements for devising neologisms are being used. This methodology introduces us to some distinct observations, especially regarding the user's inner motivations for devising and using neologisms. Although "functional" and/or "denotative" descriptions of neologisms are mentioned, much regard is paid to distinct psychological needs of the ones devising neologisms.
\end{abstract}

In sum it can be said that some neologisms are not devised for the purpose of describing new objects, but are set up in accordance to user's descriptive tastes and his sense of language.

Keywords: Chinese; neologisms; emotions and interests; psychological factors

\section{Izvleček}

Članek predlaga drugačen pogled na razloge za nastanek neologizmov, pri čemer se oddalji od razumevanja neologizmov kot novih "besed". V središče diskusije je tako postavljen uporabnik jezika s svojimi psihološkimi potrebami. Ta pristop vodi do opažanj, ki se razlikujejo od dosedanjih, posebej v povezavi z notranjimi motivi za tvorjenje in rabo neologizmov. Čeprav "funkcionalne" in/ali "opisne" razsežnosti neologizmov ne gre zanemariti, članek posveča več pozornosti internim potrebam posameznika po novih izrazih.

Raziskava pokaže, da določen segment neologizmov ne nastane zaradi potrebe po poimenovanju novih objektov, temveč odraža nagnjenja uporabnikov jezika, njihovega okusa in njihov čut za jezik.

Ključne besede: kitajščina; neologizmi; čustva in motivi; psihološki dejavniki 


\section{Definition of neologisms}

Since the end of the 19th century, a large amount of new words and expressions have emerged in the Chinese language. The origins of these neologisms are quite heteronomous, they differ in syntax as well as in structure and function. However, these neologisms have one common characteristic: they have become a reformative symbol of the modern Chinese culture.

Neologisms appearing in the time of late-Qing and early Republican era have not only become the core virtues of Chinese modernization, but have been also incorporated into the system of Chinese language. Between The Hundred Days' Reform in 1898 and the May Fourth Movement in 1919 the quantity of neologisms expanded at a rapid rate and has not slowed down since then. Thus we can all agree with Wang Li's assertion that "there have never been as many newly created Modern Chinese neologisms" and "by looking from the aspect of vocabulary, the evolving pace of Chinese language in the last 50 years far exceeded that of the past millenia." (Wang, 1958, p. 516)

Since Lü Shuxiang's first addressing of the problem of neologistic research among the linguists in 1984, a vast majority of new vocabulary dictionaries have emerged. (Lü, 1984) That enabled sinologists to gradually pay more importance to the sociological and culturological meanings of neologisms. However, these dictionaries and research institutes merely emphasized Chinese neologism's forms, structures, etymologies and representative objects.

What follows in my research article is an attempt to adopt the language user's ${ }^{1}$ point of view to rethink the linguistic phenomena that manifests in neologisms.

Broadly speaking, modern Chinese neologisms are words or expressions, which signify new notions that had been yet non-existent in late-Qing, as well as the ones that might have held a different meaning back then. (Jiang, 2004, p. 497) We can thus employ Jiang Yinghao's four factors: the first is the relationship of Chinese neologisms with "new concepts", the second takes the late-Qing circumstances into the picture, the third looks at non-existent Chinese neologisms of that era, and the last observes neologisms that may have existed before but have adopted totally different meanings throughout their history.

We could categorize vocabulary into the general and the main vocabulary. The latter presents a core part of the vocabulary, and although lesser in degree than the former, it has existed for a longer period of time and could be characterized as stabilized, regularly used, standardized and generative. (Wang, 1997, p. 125)

However, we could also categorize general vocabulary into "common vocabulary", "archaisms", "loanwords", "dialectal vocabulary", "specialized vocabulary, etc. Furthermore, we could also use the neologistic terms of "new common", "new loanword", "new dialectal" and "new specialized" vocabulary. The main vocabulary can transform into the general vocabulary, and vice-versa, which means the main and general vocabulary are mutually interchangeable. This indicates

\footnotetext{
${ }^{1}$ By the term language user I simply refer to the active subject, who may be writing or speaking the language.
} 
that general vocabulary's old and new vocabulary are both interchangeable. (Liu, 2010, p. 8)

Using the aforementioned definitions and setting a certain point in time, we can normally estimate the type of a word in the vocabulary system. This way of thinking about the relations between the Chinese language system and the new and old vocabulary is called synchronic.

However, a thoroughly different method is used if we look at this problem from the diachronical viewpoint, either by portraying a word or an expression from the time of its emergence to abolition, or through the process of its reception into the class of general word. As Liu Shuxin said:

A word or expression may be regarded as new not only if it appears from nothingness into existence, but also if it receives the general approval by the users, extensive use and has already been set up in the language vocabulary. When this kind of word has already existed in the language for a fixed amount of time, let's say for fifteen to twenty years, then the people use it with ease and the freshness has been abolished. It starts to leave the scope of a neologism as it transforms into a commonly used word. (Liu, 1990, p. 283)

This way of defining enables us to observe the time and process of the development of neologisms. It is especially important to take the factors of approval and usage into perspective, so we can observe the time of neologism's unknown identity of "not receiving general approval and not being extensively used." Apart from that, this line of thought can raise some other questions. Is it possible for a neologism to spread only in "smaller groups" or "smaller geographical regions"? In this case, can a new word really exist for a period as long as ten to twenty years? Can it turn into a common word? Is there a possibility that its usage will not be discontinued in 2-3 years? If it is used only by a minority of the populace and disappears in 2-3 years, can it still be called a neologism?

Among the definitions of neologisms, notions of a "new concept" or a "new meaning" are also frequently mentioned when discussing the vocabulary content. Wang Tiekun says:

Neologisms denote words that are either newly created or borrowed from other languages, dialects of mother languages, ancient languages or professions, or even denote a newly generated word meaning or new usage of the original word. (Wang, 1991, p. 11)

Aside from the limits of vocabulary's origins, he also brings up "meaning" and "usage".

What follows is an even more minute discussion of the definitions for vocabulary's characteristics, which emphasize three characteristics of a neologism, the "form", "meaning", and "usage", which are all encompassed by the most important focal point of "newness". From this perspective, neologisms roughly denote newly emerging words and phrases, which include words and phrases with both new forms and meanings, or with both new usages and meanings, or only with new forms. (Duan \& Zeng, 2010, p. 137) 
Again, if we put these definitions in the perspective of a relationship between the vocabulary and its denoting objects, we can say that "neologisms, simply said, are produced for denoting or annotating new things and concepts." (Fang, 2010, p. 13) Denoting and annotating are the functions of a neologism, whereas new things and concepts are objects of neologism's denotation.

From aforementioned definitions, we can observe neologisms in three definitional spheres:

1. The neologism per se: its structural shape (morphological structure); function; time of generation and the developmental process,

2. relationship between neologisms, the language system and a comparison with the original Chinese vocabulary,

3. the denoted object of a neologism: new words indicative of new concepts and things.

\section{Reasons for devising neologisms}

Regarding the reasons for devising a neologism, former scholars assumed that only by having a new concept we could say a word is a neologism. (Wang, 1958, p. 519) This illustrates a denotative standpoint for the reasons of devising neologisms. However, I claim the denoted object of a neologism not only represents a new concept.

Chen Yuan put forward a relevant comment regarding this topic:

The elements of social or any other kind of change, such as changes in societal structure, economic base, superstructure and folkways, as well as the new discoveries, inventions, technologies and breakthroughs of the scientific process, such as new concepts, new ideas, new opinions, new perceptions, are all inevitably influenced and produced by the communicating system of a language, which can be well observed through the medium of speech. Herein lies the main cause for devising neologisms. (Chen, 1998, p. 409)

Here, Chen uses a sequence of novelties, corresponding to objects denoted by the new vocabulary: new discoveries, new inventions, new technologies, new breakthroughs, new concepts, new ideas, new opinions and new perceptions.

Simply put, these novelties can be inductively summed up into two categories: that of concrete "new things" and of abstract "new matters and notions". Neologisms from the late-Qing and the early Republican era, which were collected in the 1912's Collection of new words (新名詞訓纂 Xinmingci Xunzuan), edited by Zhejiang native Zhou Qiyu (周起予), are presented using the following four categorizations:

1. The class of government (regarding aspects of political neologisms) includes 216 neologisms, such as republic, civilization, education, institutions, rights, elections, economy, law, etc. 
2. The class of academics (regarding aspects of academic neologisms) includes 97 neologisms, such as research, progress, observation, geography, astrology, ethics, physics, morals, thought, etc.

3. The class of language (regarding non-political and non-academic abstract neologisms) includes 247 neologisms, such as freedom, movement, progress, scope, stress, institution, opinion, reputation, etc.

4. The class of things (regarding neologisms of physical matter) includes 55 neologisms, such as materials, train, car, bronze statue, petroleum, annual ring, wallpaper, sea-tangle, gas, vegetation, etc.

Zhou's categorization criteria does not seem to be as clear and definite, and his ability of induction is also a bit unrefined, nevertheless it seems that he mainly thinks in two categories, namely "concerning the material" and "abstract", where the latter is a supercategory of the aforementioned political, academic and other neologisms. At that time these words represented the core ideas of "modernization", symbolized opening of China towards the world and attempts at striving for synchronicity with the world. China wanted to communicate with every country or at least keep up the pace with them, sought joint advancement, wanted to learn of their politics, academics, languages and physical matter and of the most importantly devoted its studies to learn of correspondent words and expressions. It could understand new politics, academics, languages and physical matter only by going through new vocabularies.

Zhou's compilation motives were to stress the inherency of these neologisms in the Chinese language itself, so he did not regard them as new inventions. Tang Yongchang wrote in the preface of his book that "all origins of neologisms in the classical Chinese books can be distinctively analyzed and deserve recognition." (Tang, 1912) Notwithstanding Zhou's futile effort, his book opposes the primary idea of neologism's usage and meaning being related to ancient meanings in Chinese. As an example he takes the word "democracy" from The book of History (尚書 Shangshu), which states “...the sovereign cannot achieve...” (民主罔與成厥功 Minzhu wang yu cheng jue gong), where the first two characters which nowadays mean "democracy" (民主 minzhu) actually meant "people's sovereign" or "the leader of the people". These characters have nothing in common with democracy and it could even be said the two terms are nearly opposite in meaning. In one hundred years the Chinese characters for minzhu have lost the old meaning of "people's sovereign" and have been substituted with the meaning of "democracy".

The appearance of these neologisms properly explains an attempt of contemporary people to express new concepts, feelings and physical matter by borrowing words from already existing ancient vocabulary. One reason for this is because it is hard to devise a completely new word, the other reason is because the greater part of neologisms came from Japan.

As Yang Hua said:

The most basic reason for devising neologisms is the appearance of new matters and concepts in civil life. However, the question of what kind of language forms are used to mark and reflect upon those new matters and concepts, is to a large extent 
determined by the social concepts and the psychology of language. (Yang, 2010, p. 210)

Contemporary people desired to communicate in Western standards, and when they wanted to keep up with the world, they expressed a lot of doubt in the ability of Chinese language to represent the Chinese culture. The people's social concepts and psychology of language affected the way language was used, which, in effect influenced the use of neologisms. That is why shedding light on "new matters and new concepts" cannot thoroughly explain the language user's state of mind.

Thus we should note that language users have a bit larger requirements than only using language as a tool for expressing and marking. They also pay much importance to the style and taste of expression. The function of language is not only in the indicative ability of denoting some information, but it more-so needs to meet the interests of expressive taste. This means that if we used the original vocabulary or alter and expand usages of original vocabulary, we would still create a neologism. New feelings and new interests of the language user can only be shown by using a novel feeling of a neologism.

From this we can also understand why Yan $\mathrm{Fu}$ (嚴復) and similar people strived to create translated vocabularies that corresponded with the Chinese tradition, but were in no need of obtaining a commonly used word.

Take the word "logic" for example, which entered Chinese in Ming Dynasty when Li Zhizao (李之藻) translated it as mingli tan (名理探). All until the end of Qing dynasty, it had been continuously retranslated into traditional Chinese local vocabularies by the names of bianxue (辯學), mingxue (名學), lizexue (理則學) and many others. The terms mingxue (名學) and luoji (邏輯) were also both used by Yan $\mathrm{Fu}$ (Chen, 2011, p. 4). Another commonly used term had been the Japanese translation, namely lunlixue (論理學) (Wang, 1958, p. 525), and Sun Yat-sen's later translation lizexue (理則學). Nowadays these traditional Chinese local words are not used anymore, and are instead transliterated as luoji.

The reason for non-usage of those traditional Chinese local words is not in inelegance of Yan Fu's translations; on the contrary, contemporary intellectuals commonly wanted to communicate with the world and transform the old Chinese culture by following the standards of Western civilization. If something resembled classical Chinese cultural expression, it appeared "laggard", thus contemporary intellectuals wanted to keep distance with the Chinese tradition, avoiding its influences. We can thus say that neologisms sometimes represent a new culture or new concepts in language.

\section{Neologisms devising new concepts}

A common psychological state of language users is searching for uniqueness, variety, new styles and new characteristics in language. People like unique and lively language forms as well as colorful and rich language styles. (Yang, 2012, p. 211) It is not necessary for neologisms to be devised by the influence of emerging new matters, 
things, concepts; on the contrary, it is possible for neologisms to bring new concepts or a new syntax into light. Thus seeking new states of mind and the freshness of language is frequently a major propulsion of inventing new words. (Jin, 2007, p. 46)

An especially good example is Lin Yutang's (林語堂) devisement of the neologism youmo (幽默), created in 1924 while trying to translate the English word "humor". A totally new translating invention of this word was obviously not needed, because he could use an old existing Chinese word with a similar meaning. However, Lin Yutang disfavoured literal translaton and assumed humor cannot be translated using the existing Chinese expressions for "joking” (笑話 xiaohua), “comicality” (詼 諧 huixie), or even “clownery” (滑稽 guji), neither can it be translated using the words which closely retain the essential meaning of this word, such as “wit" (風趣 fengqu), “harmonious wit” (諧趣 xiequ), or “humourous style”(詼諧風格 huixiefengge). Regardless of the straightforwardness of the transliteration, it could always be misinterpreted by other people. (Lin, 1924)

In accordance to the distinct meaning of humor, Lin Yutang first approved of words which retain some of the original meaning of humor. When he first started using a purely transliterative neologism youmo (幽默), he had not yet decided whether he wanted to use the phonetically and semantically similar word huimo (詼摹) instead. No later than a month after, he decided to use the former, as it corresponded to his intentons. The meaning of the two Chinese characters you (幽) and mo (默) does not correspond to the English word humor in any way and the two terms even hold a bit of a contradiction. The two chinese characters of you and mo could easily be misinterpreted as jingmo (靜默) or youjing (幽靜), meaning to be secluded and silent, respectively. (Lu, 1927) Lin Yutang, however, intentionally abandoned translations that employed semantic and phonetic resemblance, so he deliberately chose noncorrespondant Chinese characters, thus devising a neologism.

Of course, this was not made solely for the purpose of avoiding misunderstandings. An even more important reason is that by devising a new concept, he got rid of the unneeded disturbances and shackles of the old Chinese tradition. Despite having to do a lot of explaining, he was able to become a proponent of a new literary style, lifestyle and writing strategy. That is why transliteration is naturally in accordance with requirements of his contemporaries. (Lin, 2006)

In addition, Lin Yutang's devising of the neologism youmo was not made solely for the purpose of translating an English word, but was a part of his wish to promote a new "kind of a style in authorship or artwork", (Lin, 1924) called a "familiar essay" (小品文 xiaopinwen). He asserted that youmo is a distinguishing feature of the "familiar essay" and that the contemporary meaning of youmo slightly differs from the English word humor. Especially when he was interpreting familiar essays of Ming dynasty, the characteristic of youmo helped him retain distinctions from the English notion of humor.

Using Lin Yutang's explanations, youmo includes meanings, such as penetrating through life's wisdom, a joy of heart, lightness of brushstrokes, non-obstructiveness, not using clichés, not immitating the faceless daoistic scholars, not seeking scholarly 
joys and reputation, not aiming for a natural humour of mediocre ordinary people. (Lin, 1934)

He also quoted upon "sincerity", "broadness" and "sympathy" as the three prerequisite conditions of youmo, (Lin, 2006) which enabled this neologism to become "a kind of [his] philosophy of Buddhist compassion." (Lin, 1924) When he devised youmo, he forever contributed to the usage and meaning of this neologism, which not only received the acceptance by his contemporaries, but more-so became a very popular modern expression. For this reason Lin Yutang also recieved the title "Master of youmo", which was the driving force of the Chinese youmo literature campaign. Nowadays youmo is already a commonly used word in Chinese and has a couple of distinct usages and language feelings.

Summing up the experience of Lin Yutang's devising of a neologism youmo, we can observe these important notes:

1. He abandoned the traditional Chinese words that closely resembled literal transcription and phonetic translation.

2. He intentionally selected the words which did not corresponded to the original word in any way, and even used a contradictive vocabulary,

3. The ever changing and ever increasing meaning and usage of neologisms has also been enabled by surpassing the established (English) word meanings and usages.

In the slow proces of its devisement, youmo started off as a neologism and adopted the status of a word of the general vocabulary. At that time it could be regarded as a minor peculiarity, but nowadays in the age of fast moving information, creation processes of neologisms similar to our example, are becoming a very normal phenomenon. In the age of networking there is no doubt that following the ever changing world's technological and societal advancements, new matter and concepts are constantly emerging. Neologisms that denote new matters, things, concepts have no other option but to quickly increase in quantity. But even more importantly, the state of language users seeking novelty adds even more to the exuberant glow of neologisms. Their purpose of language usage is not restricted only to simple expression or denotation, but also to the wish of convenient exhibition of their "narrative tastes and styles" in the mass media and cyberspace. Thus language is not only a tool, it has narrative objectives as well.

Examples of Chinese neologisms “Mister De" (德先生 De Xiansheng) and "Mister Sai" (賽先生 Sai Xiansheng) could also be regarded as similar to the devising of youmo. "Mister De" can be translated as Democracy and "Mister Sai" as Science. Democracy was first translated as minzhu (民主) in 1864 (Jin \& Liu, 1999, p. 30) and kexue (科學) was used as a translation of science since 1878. (Zhou \& Ji, 2009, p. 96) However, coming into 1918 Chen Duxiu 陳獨秀 wrote in the New Youth magazine (新 青年 Xinqingnian): “It is important to support Mister De and Mister Sai, and we cannot but oppose the quintessence of our country and its old literature." He also named them as they were two real persons, namely Demokelixi (德莫克拉西) and Saiyinsi (賽因斯). (Chen, 1919) The former term became even more common after 
1920 (Jin \& Liu, 1999, p. 37), as it became an important slogan for the Chinese New Culture Movement (中國新文化運動 Zhongguo xinwenhua yundong). Mister De, Demokilixi, Mister Sai were all commonly used; however, there was no sign of minzhu and kexue, not because they were representing new concpets, but because they were not in accordance with the new feelings and meanings aroused in a large group of people towards "old concepts". The users have intentionally abandoned commonly used and well known vocabulary, and started using specific and rare neologisms to express their special feelings.

Yet another example is daren (達人), which comes from the Japanese tatsujin (た つじん), with an original meaning of a master or an expert. Master (大師 dashi) or expert (專家 zhuanjia) are words commonly used in Modern Chinese, so in fact there is no need to introduce words, such as Japanese daren. However, daren implies a "foreign style (Japanese style)" and fresh interests, which had been lacking in the old terms of master and expert. Even the most recent common practice of the youth, using instead the word gaoshou (高手), cannot compare to the neologism daren, which can better show the fresh and unique interests of language users. Since the beginning of 21 st century the word daren has appeared in Taiwan and became a popular neologism. It stands in phrases such as “the master of love” (戀愛達人 lianai daren), “the mistress of beauty” (美麗達人 meili daren), “a musical genious” (音樂達人 yinyue daren), “a great cook" (美食達人 meishi daren), “master of the household” (家事達人 jiashi daren), “a health expert” (健康達人 jiankang daren), “an excellent bartender" (調酒 達人 tiaojiu daren), “expert at savings” (省錢達人 shengqian daren), etc. The word also gradually reached Mainland China and became a commonly used neologism, as we can find the entry in the sixth edition of Modern Chinese Dictionary from 2012. Neologisms borrowed from abroad all use similar preferences, such as Chinese words for “popularity” (人氣 renqi), “a prostitute” (腐女 funü), “a woman above 30” (熟女 renü), “an unmarried woman above 30” (敗犬 baiquan), “a (male/female) geek” (宅男 /宅女 zhainan/zhainü), etc.

Another group of neologisms are formed from "sandhi",, such as Taiwan's famous jiangzi (醬子), which is a shortened version of zheyangzi (這樣子), meaning “this way“ and niangzi (醇子), a shorten of nayangzi (那樣子), meaning “that way”. By following the taste of a likable expression, this neologism became commonly imitated. Youth likes to say “jiu jiang” (就醬, meaning ”just like this“) or “jiu niang” (就釀, meaning "just like that"). Also good examples examples are biang ( |九” ) which means "not the same“ (不一樣 bu yiyang), and 881 or 886 which means "bye-bye".

The feeling of freshness in neologisms frequently takes on a large fascination and attracts a large amount of people. A Cantonese (Hongkongese) transliteration of English name for "taxi" (的士) is a great example. The Taiwanese use the native term jichengche (計程車) and in the Mainland China it is called a chuzuqiche (出租汽車).

\footnotetext{
${ }^{2}$ Sandhi comes from sanskrit's samdhí, meaning "joining". This term covers a wide variety of phonological processes that occur at morpheme or word boundaries, such as fusion of sounds across word boundaries and the alteration of sounds due to neighboring sounds or due to the grammatical function of adjacent words.
} 
Both are frequently used general vocabulary words, hence chuzuqiche for Chinese is not a fresh thing or a concept at all. But thankful to the intercultural exchange between Hong Kong and China, the word for "taxi" (的士) entered China and became a neologism, which developed a series of new words, such as $d i$ (的 as abbreviation for taxi), dadi (打的 meaning "taking a cab"), miandi (面的, commonly referred to as "a bread car", "a box shaped van", "a cab").

Creation and extinction of words can also be influenced by governmental interferences and reforms, with examples such as "a board member" (董事 dongshi), “a stockholder” (股東 gudong), “a pawnshop” (當鋪 dangpu), “bankruptcy” (倒閉 daobi), “an auction” (拍賣 paimai), “a prostitute” (妓女 jinü), “usury” (高利貸 gaolidai), "fortune telling" (算命 suanming), etc. These words had disappeared after establishing The People's Republic of China, but have been slowly reappearing again. Some other examples which express respectful cultural words that faded away during Cultural Revolution, but are gradually recuperating in use are: "await respectfully" (恭 候 gonghou), “patronize" (惠顧 huigu), “long time no see” (久違 jiuwei), “condescend" (屈尊 quzun), “fail to meet you” (失迎 shiying), r"equest the pleasure of your arrival” (賞光 shangguan), “your mother” (令堂 lingtang), “your father” (令尊 lingzun), etc.

Governmental intervention into language is however not always effective. There is an interesting example where Shanghai municipal administration once started restricting depictions on the taxi's and posted the following in 1985: "Cars which continue to use the sign with characters dishi (的士) will not be allowed to enter the streets and do business. Starting from September $1^{\text {st }}$, we unitedly start to standardize the taxi signlamps, which will state both chuzu (出租) and taxi on the front." This governmental notice has not been effective in its prohibitive demands, as the term dishi (的士) not only continued to be used but also produced a number of words deriving from the character $d i$ (的). (Yang, 2010, p. 214) This word also has its place among the entries in the Modern Chinese Dictionary, which can serve to show the power of societies looking for newness and change.

New formulation modes not only produce appearance of new words, they can also change the syntax. A good example is the use of the passive voice character bei 被 in such phrases as “to commit a suicide" (被自殺 bei zisha), "to get employed" (被就業 bei jiuye), “to volunteer” (被自願 bei ziyuan), “to donate”(被捐款 bei juankuan) and "to represent" (被代表 bei daibiao). Although not exactly logically consistent, thankful to the usage of a passive voice, they are still very important as an expression of irony and passive protest. Suicide can only be an intentional act of ending one's life, therefore bei zisha (被自殺) states an ironic saying "it is not a suicide, yet it is called as suicide." The same goes with phrases of getting employed, volunteering, donating and representing, which expressed in the passive voice seem to violate the syntax of language, but can really demonstrate the language user's protest and mockery as well as being faked and forced. This also shows the Chinese people's crisis of faith and the awakening consciousness of citizenship rights in the beginnigns of the $21^{\text {st }}$ century. 


\section{Conclusion}

Neologisms have existed since the ancient times. Investigating this topic based on the aspect of formalism or from research on new matters, new things and new concepts, can explain to us the origins of its appearance and enables us to understand its characteristics.

The majority of research concentrating on neologisms can be recollected into three aspects:

1. Neologisms form and structure per se,

2. the denoted object of a neologism,

3. relationship between a neologism and an archaism or the system of language.

If we do not reflect through the aspect of a "word", but instead change the emphasis to the language user's psychological requirements, we can obtain very different observational outcomes. Motives for devising and using neologisms are not only in the functional requirements, or in denoting new matters and concepts, but are connected to language user's psychological requirements. We can thus say that neologisms are not produced for the reason of depicting new objects, but are devised for relating to language user's new tastes of description and a sense of language.

These kinds of neologisms have some characteristic features:

1. Even if it is already sufficiently expressed in the Chinese vocabulary, neologisms can be formulated by discarding the original Chinese word by being either borrowed from foreign languages or devised completely anew.

2. When borrowed from foreign languages, the word can be clearly translated by adopting the method of literal translation, from which we can intentionally pick from non-correspondent meanings or even violate the word meaning, even to the point of using characters that have nothing to do with the translated meaning, merely following phonetic translation.

3. Even if we don't borrow from foreign languages, we can still use the method that doesn't fit the logic of language or normatives of grammar to express special emotions or language feelings.

4. Meaning and usage of neologisms can evolve and develop unceasingly.

The devising of Chinese neologisms has already transcended functional demands and this very issue deserves to be furtherly researched on the subjective grounds of emotions and interests. 


\section{References}

Chen, B. [陳波] (2011). Luojixue de diyi tang ke [邏輯學的第一堂課]. Taipei: Wunan chubanshe [五南出版社].

Chen, D. [陳獨秀] (1919). Xinqingnian zui’an zhi dabianshu [新青年罪案之答辯]. Xinqiangnian [新青年] 6(1).

Chen, Y. [陳原] (1998). Chen Yuan yuyanxue lunzhu [陳原語言學論著]. Liaoning jiaoyu chubanshe [遼寧教育出版社].

Duan, C. [段曹林], \& Zeng, C. [曾翠媚] (2010). “171 tiao xinciyu” gouci, yongci de dingliang fenxi [「171 條新詞語」構詞、用詞的定量分析]. Journal of Hainan Normal University (Social Sciences) [海南師範大學學報（社會科學版）] 23, 137-144.

Fang, Y. [方逸珮] (2010). Taiwan Riyu wailai liuxingxinci zhi yanbian yu rongru [台灣日語外 來流行新詞之演變與融入]. Furen daxue fanyi yanjiuso shuoshi lunwen [輔仁大學翻譯 研究所碩士論文].

Jiang, Y. [蔣英豪] (2007). Huang Zunxian “Jihai zashi” zhong de xinyuci [黃遵憲《已亥雜 詩》中的新語詞]. Huang Zunxian yanjiu xinlun [黃遵憲研究新論], 496-505.

Jin, H. [金惠蘭] (2007). Xiandai hanyu xinci yanjiu [現代漢語新詞研究]. Guoli zhengzhi daxue zhongwenxi shuoshilunwen [國立政治大學中文系碩士論文].

Jin, G., [金觀濤]\&Liu, Q. [ 劉青峰] (1999). “Xinqingnian” minzhu guannian de yanbian[新 青年民主觀念的演變]. The Twenty-First Century Review [二十一世紀]. Hongkong: Zhongwen dawue chubanshe [中文大學出版社].

Lin, M. [林明昌] (2006). Xingling yu beimin: Lin Yutang zaoqi youmo shuxie yanjiu [性靈與悲 憫——林語堂早期幽默書寫研究]. A Stride Over/Forward - Cultural Fusion/Function in the Study of Lin Yu-tang [跨越與前進——從林語堂研究看文化的相融/相涵國際學 術研討會].

Lin, Y. [林語堂] (1924). Youmo zahua [幽默雜話]. Chenbao fulu [晨報副錄].

Lin, Y. [林語堂] (1934). Lun youmo [論幽默]. Lunyu [論語], 33.

Liu, S. [劉叔新] (1990). Hanyu miaoxie cihuixue [漢語描寫詞彙學]. Beijing: Shangwu yinshuguan [商務印書館].

Lu, X. [魯迅] (1927). Shuo youmo yizhi fuji [說幽默譯者附記]. Mangyuan [莽原] 2(1).

Lü, S. [呂叔湘] (1984). Dajia lai guanxin xinci xinyi [大家來關心新詞新義]. Cishu yanjiu [辭書研究], 1 .

Tang, Y. [唐詠裳] (1918). Xinmingci xunzuan xu [新名詞訓纂序]. Shanghai saoyeshanfang [上海掃葉山房].

Wang, L. [王力] (1958). Hanyu shigao [漢語史稿]. Beijing: Zhonghua shuju [中華書局].

Wang, D. [王德春] (1997). Yuyanxue gailun [語言學概論]. Shanghai waiyu jiaoyu chubanshe [上海外語教育出版社].

Wang, T. [王鐵昆] (1991). 10 nianlai de Hanyu xinciyu de yanjiu [10 年來的漢語新詞語的研 究]. Yuwen jianshe [語文建設], 4.

Yang, H. [楊華] (2002). Hanyu xinciyu yanjiu [漢語新詞語研究]. Harbin: Heilongjiang jiaoyu chubanshe [黑龍江教育出版社]. 
Zhang, M. [張明輝] (2010). Lun shixia liuxing goushi/bei XXO [論時下流行構式/被 XXO.] Journal Of Guangdong Polytechnic Normal University [廣東技術師範學院學報(社會科 學) 》].

Zhongguo shehui kexueyuan yuyan yanjiusuo cidan bianji shi [中國社會科學院語言研究所詞 典編輯室] (2010). Xiandai Hanyu cidian (di 6 ban) [現代漢語詞典第六版]. Beijing: Shangwu yinshuguan [商務印書館].

Zhou, C., [周程] \& Ji, X. [紀秀芳] (2009). Jiujing shei zai Zhongguo zuixian shiyongle “kexue” yici? [究竟誰在中國最先使用了“科學”一詞? ]. Journal of Dialectics of Nature [自然辯證法通訊], 4 .

Zhou, Q. [周起予] (1918). Xinmingci xunzuan [新名詞訓纂]. Shanghai saoyeshanfang [上海掃 葉山房]. 
